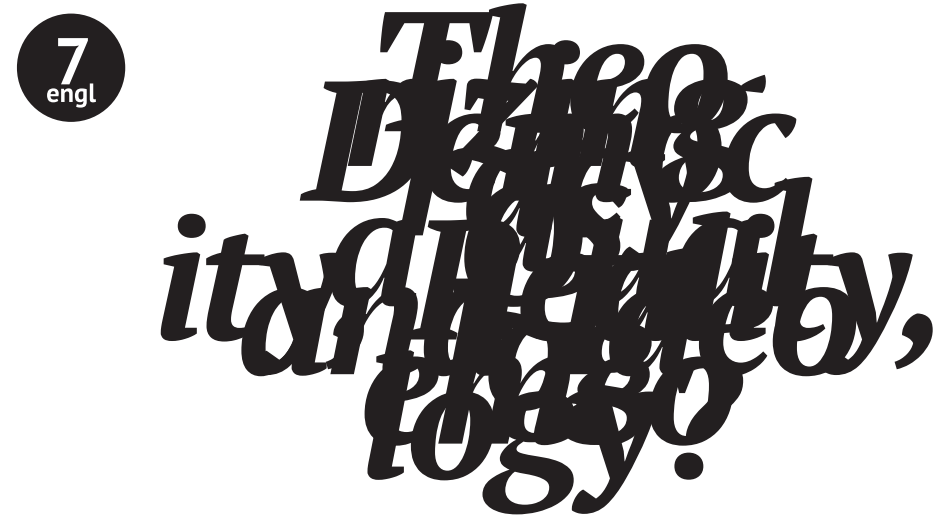

\title{
Evert van der Zweerde
}

Radboud University, Nijmegen, Netherlands

\section{Theorizing Democracy as a Quality, Reality, and Ideologeme}

\author{
Abstract \\ In today's world "democracy" and "democratic legitimacy" are \\ normatively dominant, making even the harshest dictators refer \\ to "the will of the people." At the same time, dissatisfaction with \\ "real existing democracy" is widespread and increasing, \\ particularly in long-standing democratic societies. If we \\ understand democracy, primarily, as a possible quality of practices \\ and procedures, rather than as a regime or a type of government, \\ we can address such issues. Understanding democracy as a \\ quality, consisting in those being affected by decisions having a \\ "say" in those decisions, clarifies the ongoing struggle to actually \\ have that say (which explains both the Tea Party and Nuit debout). \\ It explains how the-inevitable-institutionalization of \\ democratic practices and particularly their reduction to elections \\ leads to a gap that either invites democratic innovation, or is \\ bridged ideologically with key ideologemes like "the People" or \\ "popular sovereignty"-an ideology which is not in contradiction \\ with reality, but makes existing democratic realities more \\ democratic than they actually are. \\ Keywords \\ contestation, democracy, democratic theory, ideologeme, \\ ideology, sovereignty
}


Because we rightly believe in the basic ideal of democracy we feel usually bound to defend the particular institutions which have long been accepted as its embodiment, and hesitate to criticize them because this might weaken the respect for an ideal we wish to preserve.

Friedrich A. Hayek (1979: 1)

The power to dream / to rule

To wrestle the world from fools

It's decreed the people rule

It's decreed the people rule

People have the power.

Patti Smith, People Have the Power (1988)

The aim of this essay is to contribute to a viable political-philosophical conception of democracy, one that is reasonably plausible in terms of our experienced reality, philosophically tenable in terms of consistency, and potentially valuable in assisting us, the political animals of this planet Earth, in making sense of our political reality. Surely, the conception is hypothetical, but not in the empirical sense of stating possible facts or causal relations: as part of practical philosophy, its objective is to help us orient ourselves politically, and perhaps act accordingly as well. The paper consists of three parts: the first part offers a number of theoretical overtures that prepare the ground for the second part in which the contrast between democracy as reality and as ideology is highlighted; the third part argues that this contrast stems from the inevitable process of institutionalization that, at the same time, calls for "endless" democratic renewal. A brief conclusion states the main findings.

\section{Theoretical Overtures}

Three points of reference set the stakes of this essay. The first is the fact that since at least World War II, democracy has become a global normative standard. Independently of the degree to which political reality can be called "democratic" and although there is no objective or neutral yardstick by which to assess or measure this extent, "democracy" is generally considered "good"; democratic legitimacy is, if not the only, then certainly the most undisputed form of political legitimacy in the world today. It entered the 1948 Universal Declaration of Human Rights (UDHR), ${ }^{1}$ has

$1 \quad$ Article 21.3 of the UDHR reads: "The will of the people shall be the basis of the authority of government; this will shall be expressed in periodic and genuine elec- 
become part of numerous treaties and constitutions, and, at least verbally, of the foreign policy of major actors in international politics like the USA and the EU. As early as 1989, Russell Hanson wrote: "We live in a world that agrees on the importance and desirability of democracy," pointing to a 1951 UNESCO publication that says: "For the first time in the history of the world, no doctrines are advanced as antidemocratic. [...] This acceptance of democracy as the highest form of political or social organization is a sign of a basic agreement in the ultimate aims of modern and social institutions" (Hanson 1995: 68). Indeed, there are very few regimes in the world who do not claim to be democratic in one form or another, and even those who are such as the Kingdom of Saudi Arabia or the Sultanate of Oman are, however cautiously, introducing local elections, extending the franchise, and fostering civic participation. Regimes are often accused of being anti- or undemocratic, but none claims this of itself. Even the harshest dictatorships that have existed since 1951, say North Korea, Albania or Libya, claimed not only to be democratic but even to be particularly or eminently democratic, for example by being a people's democratic republic or a socialist democratic republic. Does this mean that Kim Il Sung, Enver Hoxha and Muammar Qaddafi "agreed on the importance and desirability of democracy"-or rather that they lived in a world where democratic talk was an integral part of international political legitimacy? When Hanson writes that the "tremendous popularity of democracy has invited appropriation by movements of every stripe" (1995: 69), he seems to be suggesting that the aforementioned figures simply held a different interpretation of democracy-this may be the case, but it shows that he misses the political dimension of discourse itself, "democracy discourse" included.

This leads to a second point of reference, namely that democracy belongs to the category of essentially contested concepts, as Walter B. Gallie has argued in his celebrated 1956 article, where democracy enjoys pride of place. Indeed, it is difficult to think of a field of political theory and political praxis in which there is greater variety of definitions, conceptions, practices, and repertoires. This variety is not so much a matter of knowledge falling short of reality, but rather of the central place of contestation in democracy: ideally, it would have to be democratically decided what democracy "means." Less ideally and more realistically one should state that this variety stems neither from a lack of understanding or knowledge, nor from cultural difference, nor, finally, from not having reached a consensus-yielding ideal speech situation, but from a basic characteristic of all political life, namely that it develops in oppositions without moving towards a synthesis. The notion of democracy itself is, I suggest, marked by the essential contestability that is proper to the political as such: as a

tions which shall be by universal and equal suffrage and shall be held by secret vote or by equivalent free voting procedures.” 


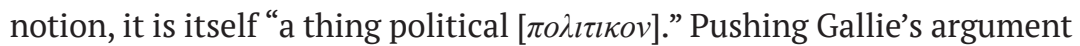
one step further, I claim that contestability belongs to the core not just of the concept, but of the political, and hence of democracy itself.

If this is true, we can turn the claim around: if something goes (fully) uncontested, it cannot be (seriously) democratic. If society always/also means struggle, then this struggle is likely to manifest itself at many levels, one of them being the public arena of democratic politics (parliaments, elections, demonstrations, petitions, etc.), another being academic debate, and a third what Jacques Rancière has aptly dubbed "the struggle over words" (2005: 101). ${ }^{2}$ The public arena, where politics is fought out, comprises not only this arena itself, but also the galleries, streets and squares around it, and the catacombs and gutters, with the open question where political space ends. Similarly, the discursive space of political speech and vocabulary is open-ended: surely, there is something like established "political language" in many places, but questions about the point where language stops or starts being political, what names and labels can or cannot do, and who decides terminology, even if always answered in practice, is open in principle, and as a rule challenged (Butler and Athanasiou 2013: 131-39). Familiar examples include the lack of words for "private property" in certain aboriginal languages or the critique of "phallocentrism" in radical feminist theory. The point can, however, be made less famously and more generally: the boundary between acceptable and unacceptable discourse will always be reproduced from the inside, attacked from the outside, and subverted from the underside. ${ }^{3}$

Against this background, I propose to understand democracy as a quality of political practices and institutions, which consists of the fact that those who are affected by political decisions have a (relatively) equal "say" in those decisions. This invokes three principles, namely equality, identity of ruling and ruled, and sovereignty of the demos, which can each be realized to a varying extent.

Democratic struggle taking the form of speech and writing, as well as other, non-verbal forms such as occupation, sit-in, or silence, is neither simply about the fact that somebody has a say, nor merely about what she or he says, but also about how it is said. Whenever political language turns into langue de bois [wooden language, dubovyi iazyk], as it does when politics is functionally differentiated into a separate domain or field, an open

\footnotetext{
Unless otherwise noted, all translations are author's own.

What happens, for example, if we engage in a political reading of Luce Irigaray's "Quand nos lèvres se parlent [When our lips speak with each other]" (1977: 20517) and pose the meta-question of where a political reading start or ends? What if we leave the context of feminist struggle and sexual differentiation, and read the text with a view to multiculturality or democracy, replacing the final word, "toute(s)" by "tou (t) (e) (s)" (Irigaray 1977: 217)? Replacing words by other words is a form of discursive politics.
} 
invitation to woodworms is implied. ${ }^{4}$ Whenever political language, for example, the notion "democracy" serves to conceal the essential contestability that makes something "political" in the first place, it becomes ideological. When this is the case is, however, itself subject to controversy.

The third point of reference, therefore, is the non-transparency of ideology. I suggest the decisive step was taken here by Louis Althusser, when he wrote: "One has to be outside ideology, that is in scientific knowledge, to be able to say: I am inside the ideology (indeed an exceptional case) or (the general case): I was in the ideology" (Althusser 1976: 127, own translation). If, however, we acknowledge that this "scientific knowledge" is, if not utopian, then certainly not manifestly given, especially when it comes to society or politics, this implies that to say "I am arguing from the standpoint of scientific knowledge" risks to be itself "in the ideology"; consequently, "I am/was in the ideology" ends up begging the question. If Althusser was right in claiming that "the ideology never says: 'I am ideological'," then at this point we must read Althusser against Althusser. The "Leninist" suggestion of a dualism of illusory or false consciousness that can be unmasked from a position of truth is itself an ideologeme. There is, however, nothing particularly Althusserian about this problem. On the contrary, theories and critiques of ideology have generally run into this problem: to diagnose an utterance as ideology presupposes a standpoint that is not only outside of this particular ideology, but outside of ideology generally. But if ideology is the "interpellation of individuals as subjects" (Althusser 1976: 127.), it becomes impossible to even pose the question in an "ideology-free" manner. The effect of this has been a dismissal of the concept of ideology, except in the sense of "political ideologies" in the plural, which can be an object of scholarly study, as practiced by authors such as Andrew Heywood (1992) or Michael Freeden (1996). Typically, these authors mention Althusser and then proceed to miss the point, that is, not to apply it to their own work.

Contrary to this tendency I suggest that, difficult as it may be, we have to address the fact of ideology and use the concept, calling "ideological" any discourse that refers to a reality that can successfully claim to be "undeniable," while at the same time jumping to general statements that, though demonstrably problematic in their generality, continue to function as part of the justification of action (or passivity) and/or legitimization of an existing state of affairs, procedure, etc. Ideology turns around the "jump" from the partial to the whole, from the particular to the universal, from the temporal to the eternal, from the local to the global, from the contingent to the necessary, or from the man-made to the

The notion of "langue de bois / wooden language / dubovyi iazyk," literally meaning "oaken language / langue de chêne" goes back to the Soviet 1920s when it was coined to designate the language used in the administrative apparatus, but acquired academic usage due to the book by Françoise Thom, La langue de bois (1987). 
natural. ${ }^{5}$ Such ideological discourse, I further suggest, has the form of a more or less coherent construction organized around one or more key ideologemes, which can be defined as its "smallest intelligible unit" (Jameson 1981: 76; Guseinnov 2005: 9-10). The crucial question then is: What happens to us, as citizens or demos-members, ${ }^{6}$ after we have read and supposedly understood Althusser or Jameson? Are we not then in the stereotypical post-Marxian condition where "we know very well what we are doing (i.e., ideologically reproducing the current prevailing socioeconomic and juridico-political order), but still we are doing it (and reading Slavoj Žižek in order not to feel too bad about it...)"? I think we are.

What happens when we say, for example, that a decision by the US president to close Guantánamo Bay-or not to close it-does have democratic legitimacy because this president was elected by the US American people? What happens is that we are "in the ideology" in the sense that we do recognize that there have undeniably been nation-wide presidential elections, the outcome of which has been accepted by all concerned, while at the same time we know about gerrymandering, low turnout, media manipulation, corporate financing, and the centripetal tendencies of the effectively bipartisan US American culture. In that culture, the president is not necessarily elected by the majority of those who voted, let alone by the majority of those who have the right to vote, and even less by "the people." At the same time, there is no denying that the US presidential elections are more democratic than those in, say, Egypt, with the exception of those won by Muhammad Morsi (Zweerde 2014: 29-31, 36-37). Ideology is what we know not to be true in its suggested generality, yet reasonably cannot deny without denying the facts or jeopardizing the very principles on the basis of which we criticize the ideologeme at stake. A telling example is the ideologeme of a particular country "being a democracy": "the Netherlands are a democracy" or even "we are a democracy" are demonstrably wrong, first because of the category mistake in-

\footnotetext{
Apart from Althusser, a major source of inspiration for this conception of ideology is Thompson (1990).

6 I use demos not as an equivalent for "the people" nor as a reference to the common, ordinary, or poor people, as the word originally did in the context of the Greek polis, but as a "technical" term indicating the set of those who have an equal (or at least relatively equal) say in the major decisions of a given polity. Often, demos is congruent with the electorate, but only if elections are the main or even only form of democracy. A situation of direct democracy does not have an electorate, but it does have a demos, and the same goes for acclamatory democracy. The demos does not have to be a majority of a given population: the exclusion of children is universal, and the inclusion of women, slaves, or workers is not a matter of course either. A polity, like ancient Athens or today's Kingdom of Saudi Arabia, in which slaves, foreign workers, and women are excluded from the demos, certainly is democratic in a very limited sense only, but we can still meaningfully distinguish between the extension of the demos in a given case, and the extent to which this demos, however limited, does "rule."
} 
volved, second because "democracy" cannot possibly be conceived of in a black and white manner of "either/or," and third because "real existing democracy" in a country like the Netherlands is a far cry from any serious conception of democracy. Yet at the same time, there is no point in denying that, in many respects, the Netherlands are "more democratic" than many other polities, and also that the Dutch "we" would not want to question the comparative yardstick invoked.

Thus, we can mark, in a first movement, the global normative status of "democracy," the essentially contested nature of not only the concept, but also the reality of democracy, and the non-transparent nature of ideology, including ideologemes regarding "democracy." In addition to these three stakes, three further points are indispensable. The first of these is a pair of definitions: I define "the political" as the dimension of possible conflict that is present in everything societal. A palm tree on an uninhabited island is not political, but a chestnut tree in the center of Kiev is, because it was planted there as a result of a decision to line a street with trees. The tree on the island becomes political as soon as somebody is claiming the island, for example because oil was discovered there. Note, however, that it is still a tree: we can claim that everything is always also political without implying that anything is ever only or merely political, and also without suggesting that everything is political to the same degree or in the same way. Further, I define "politics" as a general term that includes all forms and ways of dealing with "the political" as just defined. As a result, claiming that a tree in the centre of Kiev is "only a tree" is a form of politics-in this case, a denial of the political. General elections are a form of politics, but so are all forms of governance, all policies, as well as dictatorship, privatization (a political form of depoliticization), or the denial of the suggestion that the Olympic games are "political": to say that, for example, the 2015 European Games in Baku were not political (they were, but they were also a major sports event), and therefore not a possible target of a boycott is, itself, profoundly political, and to publish such statements in a state-sponsored glossy called Baku, is also a form of politics. So is, therefore, this very sentence. Even the poetry of Anna Akhmatova or Linton Kwesi Johnson is political. The normative claim that I make here is not that some politics are good and others are bad, but that it is better to acknowledge that something is political than to deny (or conceal) it, because the dimension of possible conflict is ubiquitous and inescapable, and will therefore manifest itself anyway. It is the necessary possibility of conflict that matters here: it explains why all measures (from property rights to ceasefires) to reduce or exclude real conflict are, themselves, inescapably political.

Second, when we speak about possible and real conflict, we are speaking about power. Any form of politics, that is, of dealing with the political, involves some or several forms of power: coercive or discursive, diplomatic or military, physical or symbolic, legitimate or brutal, governmental 
or economic, hard or soft, etc. Power I understand neither as a thing nor as a substance, but as a "relation" between forces. These forces can be of a very different nature-human sacrifice can withstand brutal state power, for example, but they need a common medium to be able to stand in a relation. Every force both presupposes and generates resistance, that is, counterforce, and power is the balance or non-balance between them. There cannot be government without opposition, and vice versa, which explains why, if there is no political opposition, government becomes governance, and opposition becomes societal resistance, refusal, stubbornness, stupidity, obstinacy. There cannot be governance without obstinacy, which explains why, if there is no obstinacy, governance becomes management, and obstinacy becomes inertia, obtuseness, or apathy. When there is no inertia, management becomes miracle: reality changes by the mere manager's wish. Even the dullest oxen needs a push or signal from its farmer in order to start moving-otherwise, the two simply become coexisting living beings. From this perspective, we can understand why, for example, bureaucracy is properly called a form of power: an official state apparatus both presupposes and generates clients and applicants who can and will spend time and energy going through the motions, filling out forms, following procedures, complaining about them, thereby slowing down, and wasting their own momentum. We can also understand why and how ideology is power: it fills discursive and symbolic space which cannot, at least not at the same time and moment, be filled by something else (surely, discursive space can be endlessly expanded, but it can be filled just as endlessly). Even apparently innocent things like a coat of arms or a picture of Europa on a Greek coin fills visual space: every time I see it, I am seeing something specific and not seeing something else in the same place and moment. Indeed, if it weren't somehow effective, why would polities spend money on putting an image on their money in the first place?

All power relations (as just indicated) are intrinsically political (as defined above), which implies that all forms of dealing with power relations are forms of politics (as defined above). Each of these forms of politics can to a greater or lesser degree be democratic. In third place, then, I understand democracy not primarily as a kind of regime or as a type of government, nor as an institution or a set of procedures, but as a (possible) quality of all of those. This quality, which can vary in intensity over time and differ from one place to another, consists in that those affected by a particular instance of politics, have a substantial and (relatively) equal say in the decisions which determine that politics. Understanding power as a relation helps us here, because it allows us to understand why, for example, both government and opposition can be, to varying extents, democratic. What the opposition (whether constructive parliamentary opposition, general strike, or color revolution) does is also politics and it affects those who take part in it. Engaging in a "color revolution" implies the risk losing one's job 
and of being beaten up by riot police (Zweerde 2015: 45-48). Also, it makes a difference if those who go on strike had a say in the decision to do so, or were, for example, manipulated by a quasi-obligatory trade union or by an authoritarian neo-fascist cell. Regimes can be more democratic or less democratic in a variety of ways. The same applies to institutions and procedures, as well as to the plurality of forms of constructive opposition that Pierre Rosanvallon has theorized as counter-democracy. Note that this analysis is not dependent on particular political positions or preferences. One can hold, as I do, that acknowledging the political is better than denying or concealing it, and also that it is generally better if people have a say in what affects them than if they don't-but of course this may well lead to outcomes that are contrary to one's political preferences as a citizen. This, by the way, is why political philosophy, though theoretical, is inescapably a form of meta-politics, that is, a way of dealing with the dimension of possible conflict that is present in the very choice for or against (more) democracy: meta-politics is not concerned with concrete societal issues or problems, but it is a form of politics nonetheless. ${ }^{7}$

\section{Democracy as Global Reality and Ideology}

So, we have the political as a dimension of possible conflict, politics as the myriad ways of dealing with the political, power as an intrinsically political relation between forces, and democracy as a possible quality of "things political." This conception is here suggested as "universal," that is, applying to all times and places. Of course, it is hypothetical, not in the Popperian sense of having to be tested against empirical evidence, but in the philosophical meaning of having to show its value in the degree to which it can assist us in making sense of our political reality. This "political reality" is one in which the political is habitually denied, politics is frequently loathed as being dirty, and politicians are generally despised. Additionally, present-day political reality is one in which "democracy" is a notion with almost an almost exclusively positive ring, and this is certainly not of all times: "Until the middle of the nineteenth century, or perhaps even later, democracy was regarded as a dangerous and unstable form of politics" (Hanson 1995: 68).

Today, we live in a period in which, as Jürgen Habermas and Francis Fukuyama have claimed in slightly different words, democratic legitimacy is the only serious option left (Habermas 2011a: 24; Fukuyama 2004: 26). This is undeniably true, but we should invoke the distinction between legitimacy as a normative concept and legitimacy as a political reality: policies often derive their legitimacy from their effectiveness, efficiency,

As such, it can itself be more democratic or less democratic: see Leijssenaar, et al (2014) for an attempt at a more democratic form of democratic theory. 
clarity, or symbolic value, none of which is necessarily connected with democratic legitimacy (see further below). Moreover, if democracy is a possible, but not necessary, quality of politics, and politics is any way of dealing with the political, necessarily involving power, then we should acknowledge that not all power is political, or, more precisely, that the extent to which power is political can differ from one situation to another. Today, for example, economic power and symbolic power are typically not political: that this is the case is, of course, profoundly political and a matter of politics, but the effect is that numerous asymmetrical power relations are not the object of politics, let alone democratic politics. Still, democratic legitimization is the major normative instrument for the public justification of positions and policies, and often appears as the only possible justification, leading to the situation where the perceived or constructed preference of an assumed majority functions as a decisive argument against any imaginable alternative: since $\mathrm{X}$ is what the people want, anything other than $\mathrm{X}$ is unacceptable. If, then, the idea of democracy dominates the normative field, while societal reality is in many respects depoliticized, democratic politics cannot possibly be the overwhelming reality. This, of course, is a truism, but it has the importance that democracy must also be ideology. Additional to being real, democracy must be ideological, too, and indistinguishably so. We knowingly simplify our own political reality with the help of an ideological construction, that is, a constellation of ideologemes.

One of the first relevant ideologemes is the notion of popular sovereignty. As Benjamin Isakhan and Stephen Stockwell claim: "Nearly all would agree with Abraham Lincoln that '[d]emocracy is the government of the people, by the people, for the people" (Isakhan and Stockwell 2012: 2). ${ }^{8}$ Yet, this is where controversy already begins if we bear in mind that one of the major sources of the notion, Jean-Jacques Rousseau, claimed that le peuple is to be sovereign, but that "government by the people" is an idea fit only for a people of gods, not of humans (Rousseau 1973 [1762]: 135). The totalitarian potential of the notion of "the sovereign people" has been sufficiently spelled out by Claude Lefort (1986: 21-23) to be assumed here-the remaining question is rather which element is more detrimental: the idea of the singularity of the people, or the idea of its assumed or desired unity. To avoid both ideas, I propose the notion of demic sovereignty as, indeed, one out of three principles that define the quality of democracy, the other two being equality and the identity of ruling and ruled. None of these three principles is ever fully realized-arguably, their full realization would be immediate self-government, which dangerously denies the political, that is, essentially contested and conflictual nature of everything societal. It allows, therefore, critical and flex-

8 Reference is to the Gettysburg Address of 19 November, 1863. 
ible application: it enables escape from the deadlock that, in established liberal democracies, "the people" is often sovereign by (constitutional) definition (Jaume 1989: 332; Maier 1998: 59; Di Fabio 2007: 15), while at the same time in the corresponding societies, if there is a "sovereign," it is certainly not "the people" nor anything close to it, but impersonal politico-economical institutions like the ECB or the IMF (Vogl 2015: 174-99). Sovereign, in the Schmittian sense, is not he, or she, or it who decides in the state of exception, but about it, that is, decides if it is the case: "Souverän ist, wer über den Ausnahmezustand entscheidet” (Schmitt 1996 [1922]: 13, own emphasis added). Most constitutions contain a definition of a state of emergency or exception, when, for example, certain constitutional rights can be temporarily suspended (te Velde 2006: 87; Di Fabio 2007: 63-66), but the sovereign decision concerns the question whether the current situation is such a state.

A second major ideologeme is related to the contrast between granted and acquired political rights. The right to democratic participationthe right to have a "say," voting rights, the right to organize oneself politically, etc.-is a political right. Political rights come in two kinds (with intermediate forms): granted rights and acquired rights. The first retain the status of a privilege even if they are universal: if the ruling family of the KSA decides tomorrow to give suffrage to all Saudi adults, men and women, they will, in terms of political rights, bring the population closer to that of many other countries. The notion of privilege, with its connotation of privation, may surprise here but it is adequate: suffrage as a right is given to some, not all (not to children, denizens, expats, animals, etc.). This contrasts with a hypothetical situation in which a popular movement claiming universal suffrage topples the Saudi clan-monarchy, replaces it with a republic and organizes presidential elections. In the latter situation, the political rights will not be granted, but successfully claimed. Part of the hybridity of the resulting situation is that many citizens still see those rights as granted to them, rather than as being claimed by themselves (a lot here also depends on the political structure of the movement that brought about regime change).

Nor is this situation endemic to reluctantly democratizing regimes. If a political regime in which citizens have political rights exists over time, the successfully claimed rights change into granted rights: members of the next generation "receive" these rights when they reach the age of, say, eighteen. If, as I suppose, people are more committed to the rights that they have acquired through their own action, than to those that have been granted to them irrespective of their action, this implies that one seed of degeneration is inevitably present in any democratic constitution, except to the extent to which those who receive political rights can understand and perceive those rights as acquired ones. This is where ideology necessarily comes in, partly in narrative form, partly in symbolic form. The infamous "We, the people..." of the US Declaration of Independence is not 
simply a historical lie (it was not "the people," but a group of persons speaking in their name, and without asking them); it is also, more importantly, a retrospective narrative that stages "the people" as an historical actor successfully claiming its right to rule itself, and an important element of the symbolic space of the USA as a polity, a key element of its symbolic order that it is nearly impossible to speak, let alone act, against. The "We, the people..." of the US American revolution is a key element in the legitimizing political autobiography of one of the world's most enduring polities. Generations of US citizens are trained to identify with this narrative and with this symbolic order and this, of course, is part of what makes them good citizens. In cases like this, we see how ideology is a form of (re)productive discursive power.

Obviously, any sustained polity possesses this type of ideology, and if some claim to be able to do without-polities in North Western Europe sometimes display this tendency - then this "being able to do without" is precisely the next ideologeme at play. Ideology, as Althusser put it, "never says 'I'm ideological'," because, obviously, its efficacy depends on not saying this (Althusser 1976: 127). To assume, however, manipulating mechanisms behind ideology, that is, to engage in conspiracy theorizing, would not only be mistaken, but also, itself, ideological: it suggests that we, as those who "see" these mechanisms, are ourselves free from them. The paradox of any critique of ideology is that of somebody who is wearing a mask saying "I'm wearing a mask" without taking it off. We knowingly engage in it. The problem with ideology generally is that it does not stand in opposition to either truth or reality, but rather is intimately connected to them, inflating and coloring both.

We can, I venture, point to a third, more anthropological reason why "democracy" must inevitably also be ideological in those cases where it is normatively hegemonic, yet not fully implemented in political reality. Hypothetically, both the figure of power-sharing and the figure of authority are deeply rooted in human practice. The plausibility both of the "democratic" argument that "we have to solve this together, therefore we should all have a say: it will yield the best solution, and it will generate the support and commitment needed to actually do it," and of the "authoritarian" argument that "someone should take the lead and take a decision: even if it is not going to be the best decision, it will at least be a clear-cut one" is, I suggest, self-evident. This is one possible explanation for the fact that we can retrace "democracy" well beyond Athenian or even Greek city-states (Keane 2009: 89-123; Isakhan and Stockwell 2012: 19-75, 123-61). Arguably, and in spite of quarrels between archaeologists and historians, we can retrace the history of authoritarianism just as far back. If we look at political practices and institutions as "human inventions," the issue would not be "what came first" (hierarchy as an extension of family relations versus collective decision-making among equals), but rather suggests the simultaneous presence of both possibilities. Our ancestors may have been, 
in this respect, pretty much like ourselves: the question is not whether we can or cannot think of "democracy" and "authority" as mutually exclusive alternatives, nor whether we generally prefer one over the other, but rather which of the two to prefer or choose in which situation. There is, moreover, a double paradox at work here: the "first" decision to address an issue in a democratic way cannot, itself, be taken democratically, just as the "first" acceptance of an authoritarian structure has to have the support of a critical majority (critical either in force or in number). Both structures therefore presuppose something like a "miraculous" transition or a "jump" which immediately invites retrospective justification or "rational reconstruction." As a result, the debate over which political structure is preferable is not accidentally endless, but intrinsically infinite. Third, whatever takes place in political history has effects beyond its own instance. Both the first democratic and the first authoritarian solution are the starting point of a habit: if successful, they are likely to be repeated, if failing, they are likely to be replaced (this points to the familiar argument about the presence or lack of "democratic experience" in particular cases). Finally, each political constellation, whether "democratic" or "authoritarian" at the outset, will become the subject of narrative and symbolic representation-in fact, narrative and symbolism (plus their own retrospective wishful thinking) are what leads historians and archaeologists to conclude that there was, at a particular time and place, "democracy."

A fourth reason why democracy is not political reality is that the "place of power" cannot be empty, not even symbolically. Arguably, no theoretician has better elaborated the idea of modern democracy than Claude Lefort. Modern democracy, he has argued, turns around the recognition that there is no "organic society" or "political body" with a single head or will, not even ideally; that "the people" is neither one nor united, but individuated and fragmented; and that, therefore, the always temporary and conditional inhabitation of the lieu du pouvoir (place of power) should not be mistaken for a legitimate occupation of the symbolic place of power. When the symbolic place of power, which once was "filled" by the "King" (or Empress, etc.) as the incorporation of legitimate political order, is not left empty, but "refilled" with the People, the Nation, the Proletariat, or a Leader, modern democracy falls short of, or more precisely stumbles beyond its idea. In reality, electoral competition turns at least partly around a number of such "fillings": not only the old ones such as the Nation or the People, but also new ones like the technocratic idea of the polity as a corporation that has to be "managed" with a focus on economic growth; the populist idea of an opposition between "real people" and the estranged elites; even the liberal-democratic political position par excel-

9 Surely, this admittedly simple polito-logical analysis is nothing but a suggestion; but it could serve as a framework for empirical (historical and archaeological) research. 
lence, that is, the defence of pluralistic and open-minded democratic republicanism, still symbolically fill the lieu du pouvoir. This inescapable "surplus gap" must be bridged ideologically by suggesting that real existing liberal-democratic polities are more Lefortian than they actually are.

The solution that arguably comes closest to the Lefortian idea is the purely symbolic constitutional monarch. In an interesting passage called "The King as a place-holder of the void" (Žižek 2002: 267-73), Slavoj Žižek has argued, using Hegel's argument in favour of constitutional monarchy, that "the King's body could also function as the very guarantee of the non-closure of the Social the acceptance of which characterizes democracy" (Žižek 2002: 267). ${ }^{10}$ The Hegelian monarch is "to serve as a protector of the empty locus of Power...; he is an empty, formal agency whose task is simply to prevent the current performer of Power (executive) from 'glueing' on to the locus of Power-that is, from identifying immediately with it” (Žižek 2002: 269). If people need something to identify with, and if the monarch is a symbolic "occupant" only, then they can identify with the monarch, or with the royal family, as being politically insignificant. This is why, paradoxically, a hereditary constitutional monarchy can be more democratic, in the Lefortian sense, than a presidential system, where the "monarch" is still elected by the majority of the population against the will of a minority. The subjectivity of the monarch, that is, the fact that she or he is a concrete human being, incarnating the "ban" on occupying the symbolic place of power, is not a setback, but on the contrary an advantage if the monarch is at the same time individual subjectivity and a will that expresses not a subjective preference, but the outcome of the political process.

Independently of Žižek, a similar point has been made by Adriaan Peperzak; Peperzak argues that within the Hegelian idea of the constitutional state, the king, ideally speaking, that is, in the case where "the final decisions of a king [are] the result of a hierarchically-structured process in which all the public levels and functions are involved... only puts the dots on the i's" (Peperzak 2001: 536). Ideally, then, it is the monarch himself who is "empty" and for that reason can fill the lieu du pouvoir. Seen from this angle, one could argue that the apolitical veneration of the King, or even of his colour (orange in the Kingdom of the Netherlands), and the gossipy attention for the royal family, rather than being in opposition are a perfect match: in venerating the figure of the monarch as a national symbol, while, at the same time, treating the person of the monarch as an ordinary human being "just like us," the monarch becomes both the highest symbol and the most ordinary fellow, thus uniting the vertical and the lateral dimensions. (Surely, this purely symbolic monarch was not what Hegel had in mind.)

10 My gratitude goes out to Pam Tönissen for pointing me to this passage. 


\section{Self-Reductive Democracy}

Democracy thus inevitably, and therefore always and everywhere, claims more "reality" than it can actually refer to, and this bridged gap is ideological in nature. At the same time, democracy remains a possible and possibly desirable quality of many constellations and situations, but it is not an entity or a thing, and this, I argue, is necessarily the case. What then happens when/if power becomes "democratic"? The democratization of power means spreading power laterally over the members of a given demos (which, in principle, can have any size and degree of homogeneity). The collective power that is thus generated is, given the acceptance of democracy as a matter of principle, legitimate by definition. Power, at the extent to which it is democratized, stops being a relationship between a state and its subjects, becoming instead a relationship between citizens and between their state and its subjects (which includes those same citizens plus all other members of a given population). With this development a vertical of power is introduced that is likely to develop its own logic of legitimacy, either in the form of actively seeking (rather than "receiving") democratic legitimization, for example by reducing democracy to FFFUCS ${ }^{11}$ or to referenda, ${ }^{12}$ particularly of the plebiscitary type, or in the form of claiming other than democratic legitimacy, for example the success of governance, the peace and quiet in society (once democratic "squabbling" has stopped), or in the form of a reference to God, Nation, History or whatever external marker of certainty (Lefort 1986: 29). A familiar hybrid form, typical for a situation in which democracy has become the global norm and therefore has to be deployed ideologically, is a reference to the Will of the People not as it is expressed in public debate or pluralistic politics, but as it is known, directly or indirectly, by an incumbent regime. Fareed Zakaria has coined the notion "popular autocracy" for this type of regime, giving the later Yeltsin period as an example, but it is also present, more generally, as a desire or phantasm, in populism (Zakaria 2004: 90-91, 96-101). There is no need to highlight the attractiveness of this model for many people, particularly when it appears in contrast to chaotic representative democracy: in a way, it is an avatar of the

11 FFFUCS stands for the standard notion in political theory of Free, Fair, Frequent, Universal, Competitive, and Secret elections as a key element of a democratic polity or constitution; for an elaboration, see van der Zweerde (2014: 31; 2015: 39-40).

12 Typical of this type of politics is not only gerrymandering, but also representatives trying to choose the right date for elections in order to be re-elected, as happened in Denmark with the general elections in 2015, or the transformation of the Dutch advisory referendum about closer association with Ukraine (61 percent "Against" and 38.2 percent "For" with a 32.3 percent turnout) into an instrument for the expression of anti-EU sentiments. Strictly speaking, there is no instrument or procedure that does not allow for its own abuse. 
age-old idea of the righteous basileus in Aristotle, the enlightened despot, or the White Tsar. Obviously, in terms of "good governance" or wise decisions, nothing excludes a priori that an enlightenend monarch or leader can do the right thing, just as obviously as a democratic constellation does not necessarily yield the best decisions. The difference between the two is about the way in which the decisions come to be and about the way in which popular support of consent is taking shape.

In late modern times, since World War II and particularly since 1989, political life is marked globally by the dynamic interaction between, on the one hand, the repeated claim by smaller or larger numbers of citizens to actually have the "say" that they are already supposed to have, and, on the other hand, the ever more sophisticated attempt by existing vertical power structures to accommodate and incorporate such democratic impulses. That liberal, and especially neoliberal, take on democratic legitimization is more about vertical than lateral democracy (the latter is rather the republican take). The typical neoliberal constellation is a combination of governance and accountability, legitimized by FFFUCS. Democratizing governance through citizens' participation and democratizing accountability through a plurality of institutionalized forms of public surveillance and control does make this neoliberal constellation more democratic, but it leaves its framework intact. What more radical impulses like Occupy, the "Arab Spring," Syriza, Tea Party, Pegida, the Dansk Folkeparti, Front National, FPÖ and PVV have in common despite their differences is that, whatever their agenda and background, they claim what they are already entitled to, namely political influence, and thereby highlight the gap between the idea and norm of political systems and their claimed reality. Their critical position is immanent to the political system, which explains why democratic impulses, whether populist or radical, end up being part of the political system: typically, they split into small radical groups that oppose the system as such, and larger "realist" groups that want to materialize the participation they already normatively have. The stability of political systems then depends on their capacity to accommodate and "canalize" these impulses.

This political dynamic is reflected at the theoretical level by attempts to conceptualize the "endless" renewal of both content and form. An example is the notion of counter-democracy developed by Rosanvallon, which not only brings into perspective the forms of organized mistrustméfiance-that develop as it were in the shadow of systems of electoralparliamentary representation, but also highlights how many of these forms sooner or later become part of the political system as a complex whole, thus inviting new forms in which this mistrust-itself of a systemic nature-articulates itself (Rosanvallon 2006). A second example is the idea of agonistic democracy defended by Chantal Mouffe (2013). It broadens, and globally so, the scope of possible forms of opposition against the hegemonic order by allowing into the political arena any position or 
movement that is ready to fight the political battle under simultaneous acceptance of a minimal set of "rules of the game," which maximizes the scope of positions within the political system (Mouffe 2013). A third, more cautious example, is presented by Habermas and other defenders of deliberative democracy, the key idea of which is that opening up the debate not only about particular decisions or policies, but also about principles and procedures, and about the very constitutional basis of the existing juridico-political system itself, keeps the political system open for future adaptation, even if for Habermas a normative framework remains in place (2011b). What these positions share, despite their differences and mutual polemics, is their objective to broaden the space of articulation and acceptance within the framework of a liberal-democratic rule of law state, thus jointly suggesting that we are not capable of conceiving anything better, and therefore must focus our energy on closing the ever re-emerging gap between idea and reality by inviting real political dynamics, rather than covering it up ideologically. ${ }^{13}$ On grounds of principle, indicated above, however, there will always remain a gap and hence a need to cover it up ideologically.

If we assume that it is true that "we political philosophers" cannot come up with anything better, more balanced, and more well-conceived, than a combination of liberal, democratic, and rule of law-or constitutional-principles, while at the same time it is true that "we inhabitants of the planet Earth" are deeply dissatisfied with the allegedly democratic polities that we live in, we may pause and ask ourselves why democracy cannot be brought to perfection. Apart from general human finitude and fallibility, we can point to more systemic reasons. One already suggested above is that no political system, whatever its nature, idea, or principles, ever exhausts the field of power, which implies that other constellations of power, for example economic, cultural, or moral ones, interfere with the political system. The other is that the combination of liberalism, democracy, and rule of law is less tight, and therefore less stable, than is often suggested. Leaving rule of law aside for the moment, we can look at the expression "liberal democracy" itself. Given that a whole range of authors, from Carl Schmitt to Fareed Zakaria, and including Michael Oakeshott and Norberto Bobbio, have claimed that liberalism and democracy neither imply nor presuppose each other, thus indicating possibilities like illiberal democracy and liberal authoritarianism, the very expression itself, repeated ad nauseam in both political science and actual politics, is an ideologeme. It does point to a reality, but turns it into more than it is, thus justifying its gap.

Indeed, liberalism and democracy are compatible, that is, they do not exclude each other, but they do not imply each other either: liberalism

13 With this, I am not suggesting that the authors just mentioned succeed in avoiding ideology. 
needs to be specified in terms of which freedoms (only libertarians will argue: all freedoms except those that keep others from realizing their freedom-and even there, the problem is not with the harm principle as such, but with its concrete application: when does the freedom of X keep Y from realizing hers?), and democracy is essentially contested (only conservatives will argue that we must stick to what we have because it is already the best of all possible political realities-manifest injustices and manifest incapacities of governments to solve issues will, however, always put this conservatism under pressure). Against Schmitt, I do not think that democracy and (political) liberalism are necessarily in contradiction with each other (1996 [1923]: 13), ${ }^{14}$ but with him, I do think that democracy and (political) liberalism neither imply, nor presuppose each other, and therefore can be antithetical. One of the founding fathers of neoliberalism, Friedrich von Hayek, wrote: "Liberalism and democracy, although compatible, are not the same... the opposite of liberalism is totalitarianism, while the opposite of democracy is authoritarianism. In consequence, it is at least possible in principle that a democratic government may be totalitarian and that an authoritarian government may act on liberal principles... [in] demanding unlimited power of the majority, [democracies] become essentially anti-liberal" (quoted in Mirowski 2014: 84). ${ }^{15}$ In Hayek's view, this points to the fact that "democracy needs even more severe restraints on the discretionary powers government can exercise than other forms of government, because it is much more subject to effective pressure from special interests, perhaps of small numbers, on which its majority depends" (Hayek 1979: 129).

Following Hayek, we obtain four possibilities: liberal democracy, liberal authoritarianism, totalitarian democracy, and totalitarian authoritarianism. Arguably, two of these, namely liberal democracy and liberal authoritarianism, dominate the world politically, while totalitarian democracy and totalitarian authoritarianism have largely left the scene. Democracy is compatible with dictatorship, with majority tyranny, and with suppression or exclusion from the demos of substantial parts of a given population. Liberalism is compatible with oligarchy, with aristocracy, and with economic exploitation of the vast majority of a given population. Critics of both liberalism and democracy are easily found, but they rarely articulate anything else than improved versions of both: true freedom instead of merely economic and individualistic liberty, genuine democracy instead of the degenerated electoral systems that citizens make the best

14 Democracy and economic liberalism, by contrast, arguably are in contradiction, since economic liberalism leads to differences in wealth that undermine citizens' equality to such an extent that democracy becomes a sham-again, the key example is provided by the USA, but there are many others.

15 Mirowski is referring to Hayek's Studies in Philosophy, Politics and Economics (1967: 161). 
of. The fact, however, that theorists have a hard time coming up with something better than a restatement of the combination of democratic and liberal principles - with, as a third element, the notion of rule of law or Rechtsstaat-is not, as flat-footed Hegelians might think, a mere legitimization of political reality, but rather, as sophisticated Hegelians will argue, proof that one cannot easily fall back behind already achieved ideas. That, too, is our reality.

At the same time, authoritarian regimes in the contemporary world will typically not argue that there is something wrong with freedom or with democracy, but rather that what they represent is either a better version of them, or their own culturally specific variant. As a result, limiting myself to "democracy"-but noting that this is an abstraction-a large variety of phenomena in the world is given the label "democratic" irrespective of the actual degree of the quality "democracy" of the phenomenon in question, that is, that those affected by a particular instance of politics have a substantial and (relatively) equal say in the decisions that determine such politics. If a label sticks to something, relatively irrespective of the extent to which that something displays the quality stated on the label, we are dealing with a case of ideology, and what the label says is an ideologeme. An almost literal example of this is the official name of present-day Greece, E $\lambda \lambda \eta v i \kappa \eta ~ \delta \eta \mu о к \rho \alpha \tau \iota \alpha$, proudly appearing on its coins and postage stamps, but in stark contradiction with the recent referendum on EU-imposed austerity policies: the referendum's outcome (61.3 percent "No" vs. 38.7 percent "Yes" with a 63 percent turnout) was ignored by the government who organized it, which resulted in a drop in electoral turnout of little over 50 percent in the next elections.

One misconception appears in full force here: the opposition of "genuine" and "fake." Once people start discovering that there is something fake about their current situation, for example, when they conclude that the liberal-democratic polity of which they are citizens is, in fact, sham democracy, they rarely, if ever, resist the temptation to look for the real thing. In US American political theory, for example, and especially in the more radical, libertarian variants, there is a strong tendency towards re-rooting and re-birthing. The construction of an opposition of principle between the current, degenerated, corrupted, or "sold out" situation and a past (or future, or distant) situation in which the same principles are realized in pure, unspoilt form, is, precisely, the crucial ideological move at play. By reaching back either to the glorious days when "the people" decided they would rule themselves, or to the original New England township democracy, theoreticians look for the pure, that is, unspoilt, and the true, that is, non-ideological variant of what the current, imperfect and ideological, variant tells them is reality. In this, they differ very little, if at all, from those Muslims who refer back to the period of the righteous caliphs, in the earliest period of Islam. This typically goes along with an "In the beginning...” narrative (of which the Qur'an like the Old Testament is 
an example), as opposed to a plurality of "Once upon a time..." narratives, which as Bonnie Honig following Michael Oakeshott has argued, are connected with monological as opposed to polyphonic discourse, "monarchic" as opposed to "poly-archic" politics, and with People-as-One as opposed to multitude (Oakeshott 1976: 105; Honig 2009: 36ff.).

There is no doubt that in itself to have elections is more democratic than not to have them, just as there is no doubt that fair elections are more democratic than unfair ones, frequent ones more democratic than ones that take place only once and end up in elected authoritarianism. It is, however, just as undeniable that citizens of established democratic systems are increasingly and structurally dissatisfied with the "say" that their systems give them. One of the paradoxes of democratic politics is that, once FFFUCS have been established, often as a result of prolonged political struggle-the struggle for universal suffrage was struggle-they enter a process in which they turn from achievement into ideologeme. The greatest barrier against democratic innovation, in all "mature" democracies, is attachment and commitment to the already achieved. In all likelihood, the progressive "neoliberal dedemocratization" (Brown 2015: 77) that widens the gap between democratic reality and its ideological legitimization will continue to reduce this attachment and commitment, and will displace calls and cries for democracy to spacesstreets, squares, catacombs and gutters-outside established politics. While the capacity of society to reinvent itself politically is in principle infinite, implying that it can always become more or less democratic, no degree of the quality of democracy can even fully meet its own internal yardstick-particularly not when political practices and repertoires stabilize and become institutionalized, as they necessarily will. Disillusionment and dissatisfaction are as inevitable as is the invocation of ideologemes that legitizime the existing situation as the maximum or optimum of "democracy."

\section{Conclusion}

The aim of this essay was to contribute to a viable, that is, reasonably plausible, philosophically tenable, and practically valuable conception of democracy. In the course of this endeavour I hope to have shown that the combined facts of democracy's hegemony as a normative idea, and the necessarily limited nature of the presence of the quality "democracy" in actual political reality, inevitably point to the proliferation of "democratic ideology" in the form of a number of ideologemes that while referring to undeniable democratic realities, raise the generalized democratic claim beyond plausibility. The extent to which we, political philosophers, have a hard time coming up with anything better, and thus remain attached to the democratic principle that those who are affected by particular policies 


\section{Evert van der Zweerde}

are entitled to have a substantial and (relatively) equal say in the decisions that determine those policies, while at the same time we, as world inhabitants, cannot deny being deeply dissatisfied or, in a number of socalled new democracies, deeply disappointed with "real existing democracy," we-both as philosophers and as inhabitants-are in dire straits. In fact, we-again, both as theoreticians and as real or wannabe citizensare forced into the embarrassing situation of having to argue in terms of relative progress and recession.

\section{Bibliography}

Althusser, Louis (1976). “Idéologie et appareils idéologiques d’État.” In Positions, 79137. Paris: Éditions Sociales.

Brown, Wendy (2015). Undoing the Demos: Neoliberalism's Stealth Revolution. New York: Zone Books.

Butler, Judith, and Athena Athanasiou (2013). Dispossession: The Performative in the Political. Cambridge: Polity.

di Fabio, Udo, ed. (2007). Grundgesetz. München: DTV.

Freeden, Michael (1996). Ideologies and Political Theory: A Conceptual Approach. Oxford: Clarendon Press.

Fukuyama, Francis (2004). State-Building, Governance and World Order in the $21^{\text {st }}$ Century. Ithaca, NY: Cornell University Press.

Gallie, Walter B. (1956). "Essentially Contested Concepts.” Proceedings of the Aristotelian Society $56: 183-87$.

Guseĭnov, Gasan (2005). Karta nashě rodiny: ideologema mezhdu slovom i telom [Map of our homeland. Ideology between word and body]. Moscow: O.G.I.

Habermas, Jürgen (2011a). “'The Political': The Rational Meaning of a Questionable Inheritance of Political Theology.” In The Power of Religion in the Public Sphere, eds. Eduardo Mendieta and Jonathan VanAntwerpen, 15-33. New York: Columbia University Press.

Habermas, Jürgen (2011b). Zur Verfassung Europas. Frankfurt am Main: Suhrkamp.

Hanson, Russell (1995). “Democracy” [1989]. In Political Innovation and Conceptual Change, eds. Terence Ball, James Farr, Russell L. Hanson, 68-89. Cambridge: Cambridge University Press.

Hayek, Friedrich A. (1967). Studies in Philosophy, Politics and Economics. New York: Simon \& Schuster.

Hayek, Friedrich A. (1979). Law, Legislation and Liberty, vol. 3: The Political Order of a Free People. Chicago: University of Chicago Press

Heywood, Andrew (1992). Political Ideologies: An Introduction. Basingstoke: Palgrave Macmillan.

Honig, Bonnie (2009). Emergency Politics; Paradox, Law, Democracy. Princeton, NJ: Princeton University Press.

Irigaray, Luce (1977). “Quand nos lèvres se parlent.” In Ce sexe qui n'en est pas un, 20317. Paris: Minuit. 


\section{Theorizing Democracy as a Quality, Reality, and Ideologeme}

Isakhan, Benjamin, and Stephen Stockwell, eds. (2012). The Secret History of Democracy. Basingstoke: Palgrave Macmillan.

Jameson, Fredric (1981). The Political Unconscious; Narrative as a Socially Symbolic Act. Ithaca, NY: Cornell University Press.

Jaume, Lucien, ed. (1989). Les declarations des droits de l'homme (du Débat 1789-1793 au

Préambule de 1946). Paris: Flammarion.

Keane, John (2009). The Life and Death of Democracy. London: Pocket Books.

Lefort, Claude (1986). Essais sur le politique. XIX ${ }^{e}-X X^{e}$ siècles. Paris: Éditions du Seuil.

Leijssenaar, et al (2014). Futures of Democracy, eds. Bas Leijssenaar, Judith Martens and Evert van der Zweerde. Eindhoven: Wilde Raven.

Maier, Pauline, ed. (1998). The Declaration of Independence and the Constitution of the United States. New York: Bantam Books.

Mirowski, Philip (2014). Never Let a Serious Crisis Go to Waste. London: Verso.

Mouffe, Chantal (2013). Agonistics: Thinking the World Politically. London: Verso.

Oakeshott, Michael (1975). On Human Conduct. Oxford: Clarendon.

Peperzak, Adriaan T. (2001). Modern Freedom; Hegel's Legal, Moral, and Political Philosophy. Dordrecht: Kluwer Academic.

Rancière, Jacques (2005). La haine de la démocratie. Paris: La fabrique.

Rosanvallon, Pierre (2006). La contre-démocratie; la politique à l'âge de la défiance. Paris: Éditions du Seuil.

Rousseau, Jean-Jacques (1973). Du contrat social [1762]. Paris: Union Générale d’Éditions.

Schmitt, Carl (1996 [1922]). Politische theologie: vier kapitel zur lehre von der souveränität. Berlin: Duncker \& Humblot.

Schmitt, Carl (1996 [1923]). Die geistesgeschichtliche lage des heutigen parlamentarismus. Berlin: Duncker \& Humblot.

te Velde, Henk, ed. (2006). De grondwet van Nederland. Amsterdam: Athenaeum-Polak \& Van Gennep.

Thom, Françoise (1987). La langue de bois. Paris: Julliard.

Thompson, John B. (1990). Ideology and Modern Culture. Cambridge: Polity Press.

Vogl, Joseph (2015). Der souveränitätseffekt. Zürich: Diaphanes.

Zakaria, Fareed (2004). The Future of Freedom: Illiberal Democracy at Home and Abroad. New York: Norton.

Zweerde, Evert van der (2013). “The Rise of the People and the Political Philosophy of the Vekhi Authors." In Landmarks Revisited; The Vekhi Symposium 100 Years On, eds. Robin Aizlewood and Ruth Coates, 104-27. Boston: Academic Studies Press.

Zweerde, Evert van der (2014). “Democracy or Islam? Yes, Please!! Political Progress in Egypt.” In Futures of Democracy, eds. Bas Leijssenaar, Judith Martens and Evert van der Zweerde, 24-43. Eindhoven: Wilde Raven.

Zweerde, Evert van der (2015). “Democratic Repertoires: the South Caucasus case(s).” In Religion, Nation and Democracy in the South Caucasus, eds. Alexander Agadjanian, Ansgar Jödicke and Evert van der Zweerde, 38-56. London: Routledge.

Žižek, Slavoj (2002). For They Know Not What They Do: Enjoyment as a Political Factor [1991]. London: Verso. 